\title{
Protein Kinase $C \zeta$ and Glycogen Synthase Kinase-3 $\beta$ Control Neuronal Polarity in Developing Rodent Enteric Neurons, whereas SMAD Specific E3 Ubiquitin Protein Ligase 1 Promotes Neurite Growth But Does Not Influence Polarity
}

\author{
Bhupinder P. S. Vohra, Ming Fu, and Robert O. Heuckeroth \\ Departments of Pediatrics, and Molecular Biology and Pharmacology, Washington University School of Medicine, St. Louis, Missouri 63110
}

\begin{abstract}
Enteric nervous system (ENS) precursors migrate extensively before differentiating to form uni-axonal or multi-axonal neurons. ENS precursor survival, neurite growth, and cell migration are all directed by Ret kinase, but downstream signaling pathways are incompletely understood. We now demonstrate that proteins regulating polarity in other cells including partitioning defective 3 (PAR3), PAR6, protein kinase $\mathrm{C} \zeta$ (PKC $\zeta)$, and glycogen synthase kinase $3 \beta(\mathrm{GSK} 3 \beta)$ are expressed in developing enteric neurons with a polarized distribution. Blocking PKC $\zeta$ or GSK $3 \beta$ reduces ENS precursor migration and induces the formation of multi-axonal neurons. Axon elongation also depends on SMURF1 (SMAD specific E3 ubiquitin protein ligase 1), which promotes RhoA degradation and associates with polarity proteins. SMURF1 inhibition, however, does not increase the number of multi-axonal neurons in ENS precursors. These data link cell surface Ret activation with molecular machinery controlling cytoskeletal dynamics and suggest that polymorphisms influencing PKC $\zeta$ or GSK3 $\beta$ might alter Hirschsprung disease penetrance or expressivity by affecting ENS precursor migration.
\end{abstract}

Key words: neuronal polarity; migration; axon specification; partitioning proteins; intracellular signaling; neurite

\section{Introduction}

Enteric nervous system (ENS) development requires directed cell migration and precursor differentiation to produce a neuronal network that controls motility and responds to intestinal stimuli (Gershon, 1997; Furness, 2000; Newgreen and Young, 2002a,b). Distinct enteric neuron subtypes differentiate into cells with diverse neurotransmitter expression patterns, electrophysiology, morphology, and function. For $>100$ years, morphology of enteric neurons has been used as a basis for classification (Dogiel, 1899). This includes "multi-axonal (type II neurons)" and "multi-dendritic, uni-axonal" neurons whose function correlate to some degree with morphology (Brehmer et al., 1999). Because both directed migration and axon specification require cell polarization, we hypothesized that these processes share common molecular mechanisms within the developing ENS.

Polarization is essential for many aspects of development, including asymmetric cell division and establishment of polarized epithelia (Wodarz, 2002; Etienne-Manneville and Hall, 2003a). Recent work has demonstrated that these disparate processes use

\footnotetext{
Received Feb. 26, 2007; revised June 7, 2007; accepted July 6, 2007.

R.0.H. was supported by National Institutes of Health (NIH) Grants R01 DK57038 and R01 DK6459201, Digestive Disease Research Center Core NIH Grant P30-DK52574, and March of Dimes Grant FY02-182. We thank Dr. Jeffrey Milbrandt and Dr. Louis Muglia for thoughtful comments about this manuscript and Dr. Moses Chao for sharing his p75 ${ }^{\text {NTR }}$ antibody.

Correspondence should be addressed to Dr. Robert 0 . Heuckeroth, Department of Pediatrics, Washington University School of Medicine, 660 South Euclid Avenue, Box 8208, St. Louis, M0 63110. E-mail: heuckeroth@kids.wustl.edu.

DOI:10.1523/JNEUROSCI.0870-07.2007

Copyright $\odot 2007$ Society for Neuroscience $\quad$ 0270-6474/07/279458-11\$15.00/0
}

the same proteins to establish asymmetry and link extracellular signals to the cytoskeleton. This protein complex is organized by PAR (partitioning defective) proteins first discovered in Caenorhabditis elegans mutants that failed to specify anterior/posterior axis (Kemphues et al., 1988). Subsequent work demonstrated that a complex of PAR3/PAR6/atypical protein kinase C (PKC)/ cell division cycle 42 (Cdc42) is essential for asymmetric cell division in yeast (Chant, 1999), anterior/posterior polarity in $C$. elegans (Nance, 2005), neuroblast polarity and axon specification (Shi et al., 2003; Wiggin et al., 2005), astrocyte migration (Etienne-Manneville and Hall, 2003b), and tight junction formation and epithelial to mesenchymal transition (Ozdamar et al., 2005). Furthermore, in astrocytes, Cdc42 activates PKC $\zeta$, which directly inhibits glycogen synthase kinase $3 \beta$ (GSK3 $\beta)$ in a spatially restricted manner to direct motility (Etienne-Manneville and Hall, 2003b). GSK3 $\beta$ is a serine/threonine kinase with many substrates, including microtubule-associated proteins MAP1B, tau, adenomatous polyposis coli, collapsin response mediator protein 2, and the kinesin light chain microtubule motor (Cole et al., 2004; Jope and Johnson, 2004; Quach et al., 2004; Yoshimura et al., 2005). Thus, GSK3 $\beta$ directly influences microtubule growth and transport along microtubules required for axon growth and cell migration. Recent evidence in hippocampal neurons demonstrated that GSK $3 \beta$ also plays a central role in the maintenance and establishment of neuronal polarity (Jiang et al., 2005; Yoshimura et al., 2005, 2006).

We now demonstrate important roles for PKC $\zeta$ and GSK $3 \beta$ in cell body migration and axon specification in the developing 

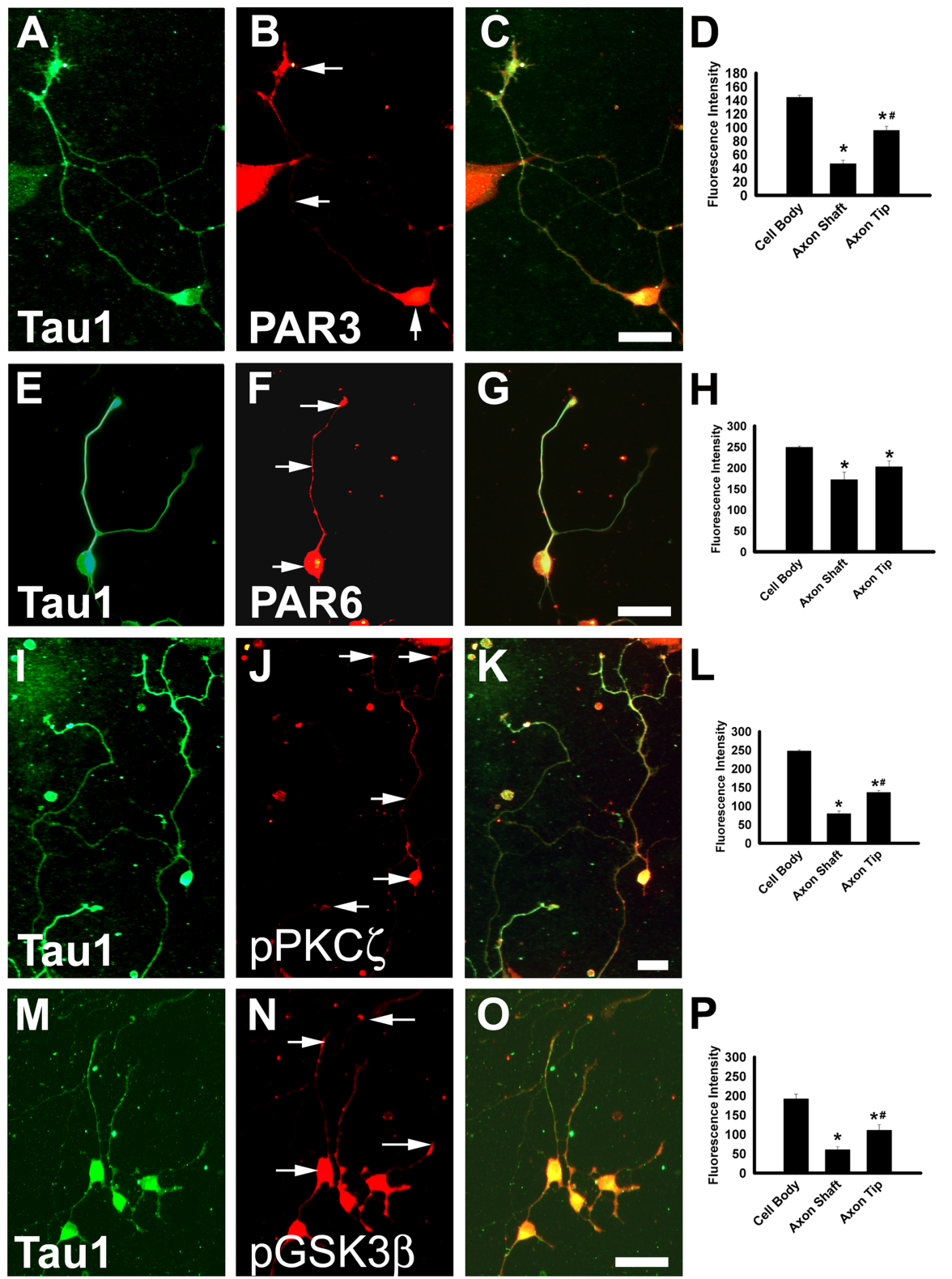

Figure 1. PAR3, PAR6, PKC $\zeta$, and GSK3 $\beta$ are produced in developing enteric neurons with a polarized distribution. E14.5 rat immunoselected ENS precursors maintained in culture for $48 \mathrm{~h}$ were stained with antibodies that recognize the axonal protein TAU1 $(\boldsymbol{A}, \boldsymbol{E}, \boldsymbol{I}, \boldsymbol{M})$ or with antibodies to PAR3 $(\boldsymbol{B})$, PAR6 $(\boldsymbol{F})$, phosphorylated PKC $\zeta(\boldsymbol{J})$, or phosphorylated GSK3 $\beta(\boldsymbol{N})$. Merged images are shown in $\boldsymbol{C}, \boldsymbol{G}, \boldsymbol{K}$, and $\boldsymbol{O}$. Protein localization in the neuron cell body, axon shaft, or axon tip was determined by quantitative analysis of fluorescence intensity using NIH ImageJ $1.30(\boldsymbol{D}, \boldsymbol{H}, \boldsymbol{L}, \boldsymbol{P})(n=50$ cells per analysis). Arrows indicate the location of fluorescence intensity measurements. ${ }^{*} p<0.01$ compared with cell body. ${ }^{\#} p<0.01$ compared with axon shaft. Scale bars, $50 \mu \mathrm{m}$.

ENS. Furthermore, because neurite growth and cell migration in model systems require localized RhoA inhibition, we tested the hypothesis that, PCK $\zeta$ and PAR6 interact with the HECT domain E3 ubiquitin ligase SMURF1 (SMAD specific E3 ubiquitin protein ligase 1), shown recently to control RhoA degradation in active cellular protrusions and to regulate cell polarity (Wang et al., 2003). These studies demonstrate that SMURF1 is expressed in ENS precursors in a similar pattern to PAR3, coimmunoprecipitates with a PAR6, GSK3 $\beta$, and PKC $\zeta$, and critically influences neurite growth but does not alter axon-dendrite polarity. These observations have important implications for Hirschsprung disease, a potentially fatal developmental disorder of the ENS in which variable expressivity and partial penetrance is com- mon, and the phenotype often depends on the presence of hypomorphic mutations in several genes.

\section{Materials and Methods}

Materials. The following primary antibodies were used: p75 ${ }^{\mathrm{NTR}}$ antibody 9651 (1:1000; generous gift from Dr. Moses Chao, New York University Medical Center, New York, NY) (Huber and Chao, 1995), mouse anti-TAU1 (1: 100; Chemicon, Pittsburgh, PA), TAUpS396 (1: 1000; Invitrogen, Carlsbad, CA), rabbit TuJ1 (1: 1000) and mouse TuJ1 (1:100; Covance, Denver, CO), rabbit anti-PAR3 (1:100; BD Biosciences, San Jose, CA), rabbit anti-PAR6 (1: 100) and anti-SMURF1 (1:50; Santa Cruz Biotechnology, Santa Cruz, CA), rabbit antiphospho-PKC $\zeta$ (p-PKC $\zeta)(1: 100)$, and antiphospho-GSK3 $\beta$, anti-PKC $\zeta(1: 100)$, and antiGSK3 $\beta$ (1:100; Cell Signaling Technology, Danvers, MA). The secondary antibodies used were Alexa Fluor 350-, 488-, and 594conjugated anti-mouse and anti-rabbit antibodies (1:500; Invitrogen). GSK3 $\beta$ inhibitors 3-(2,4-dichlorophenyl)-4-(1-methyl-1H-indol3-yl) $1 H$-pyrrole-2,5-dione (SB216763) and 3-[(3-chloro-4-hydroxyphenyl)amino]-4-(2nitrophenyl)-1H-pyrrole-2,5-dione (SB415286) were from Tocris Bioscience (Ellisville, MO). Bisindolylmaleimide, myristoylated pseudosubstrate inhibitor selective for $\mathrm{PKC} \zeta$, and Rhoassociated coiled-coil containing protein kinase (ROCK) inhibitors (R)-(+)-trans- $\mathrm{N}-(4-$ pyridyl)-4-(1-aminoethyl)-cyclohexanecarboxamide (Y-27632) and (S)-(+)-2-methyl-1[(4-methyl-5-isoquinolinyl)sulfonyl]homopiperazine $(\mathrm{H}-1152 \mathrm{P})$ were from Calbiochem (San Diego, CA).

Primary culture of immunoselected ENS precursors. Enteric neural crest were immunoselected from embryonic day 14.5 (E14.5) Sprague Dawley rat (Charles River Laboratories, Wilmington, MA) small bowel and colon using p $75^{\text {NTR }}$ antibody (Wu et al., 1999). Bowel was dissociated with collagenase $(1 \mathrm{mg} / \mathrm{ml})$ and dispase $(1 \mathrm{mg} / \mathrm{ml})$ to yield a single cell suspension. After p $75^{\mathrm{NTR}}$ antibody incubation ( 9651 ; 1:1000, $1 \mathrm{~h}, 4^{\circ} \mathrm{C}$ ) in B27 (Invitrogen) supplemented Neurobasal medium, cells were incubated with goat anti-rabbit coupled paramagnetic beads $\left(1: 50,1 \mathrm{~h}, 4^{\circ} \mathrm{C}\right.$; Miltenyi Biotec, Bergisch Gladbach, Germany) before separating neural crest-derived cells from unselected cells with a positive selection column (MACS separation columns; Miltenyi Biotec). Immunoselected crest-derived cells were plated at a density of 500 cells per well on poly-D-lysine/laminin-coated eight-well chamber slides (Biocoat; Fisher, Pittsburgh, PA) in B27 supplemented Neurobasal medium plus $50 \mathrm{ng} / \mathrm{ml}$ glial cell line-derived neurotrophic factor (GDNF). In all experiments, inhibitors were added to the medium $6 \mathrm{~h}$ after plating using $5 \mu \mathrm{M} \mathrm{SB} 216763$ and 10 $\mu \mathrm{M}$ SB415286 (GSK3 $\beta$ inhibitors), $50 \mathrm{~nm}$ bisindolylmaleimide (PKC inhibitor), $10 \mu \mathrm{M}$ myristoylated pseudosubstrate inhibitor selective for $\mathrm{PKC} \zeta$, or $10 \mu \mathrm{M}$ Y-27632 or $10 \mathrm{~nm} \mathrm{H-1152P} \mathrm{(ROCK} \mathrm{inhibitors).} \mathrm{Cells} \mathrm{were} \mathrm{main-}$ tained in a humidified environment $\left(5 \% \mathrm{CO}_{2}, 37^{\circ} \mathrm{C}\right)$ for $48 \mathrm{~h}$ before washing with PBS and fixing in $4 \%$ paraformaldehyde $\left(25^{\circ} \mathrm{C}, 20 \mathrm{~min}\right)$. For gene expression experiments, cells were grown in B27 supplemented Neurobasal medium plus $50 \mathrm{ng} / \mathrm{ml}$ GDNF for 24, 48, or $72 \mathrm{~h}$. All experiments were performed in triplicate. All analyses were performed blinded. 
Immunohistochemistry and image analysis. After fixation, cells were washed with PBS, blocked with $4 \%$ normal donkey serum in TBST (Tris-buffered saline plus $0.1 \%$ Triton $\mathrm{X}-100)\left(1 \mathrm{~h}, 37^{\circ} \mathrm{C}\right)$, and then incubated in primary antibody $\left(4^{\circ} \mathrm{C}\right.$ overnight $)$. Antibody binding was visualized with Alexa Fluor 350-, 488-, and 594-conjugated anti-mouse and antirabbit secondary antibodies $\left(25^{\circ} \mathrm{C}, 1 \mathrm{~h}\right)$. Images were obtained with an Olympus Optical (Tokyo, Japan) BX60 microscope and an Axiocam digital camera and AxioVision imaging software (Zeiss, Oberkochen, Germany). Photoshop 7.0 (Adobe Systems, San Jose, CA) was used to adjust contrast and brightness so that digital images appear as they did when observed directly through the microscope. Image analysis was performed with NIH Image 1.30.

Immunoprecipitation studies. For each immunoprecipitation, $\mathrm{p} 75^{\mathrm{NTR}}$-positive $\left(\mathrm{p} 75^{\mathrm{NTR}+}\right) \mathrm{im}$ munoselected cells derived from 50 embryos (E14.5, rat) were maintained in culture for $2 \mathrm{~d}$ on fibronectin-coated plastic dishes in B27 supplemented Neurobasal medium plus $50 \mathrm{ng} / \mathrm{ml}$ GDNF. Cells were lysed in $1 \mathrm{ml}$ of $100 \mathrm{~mm}$ Tris, $0.5 \%$ Triton $\mathrm{X}-100, \mathrm{pH} 7.6$, plus protease inhibitor cocktail (Complete Mini; Roche, Penzberg, Germany) by repeatedly drawing suspended cells through a 21 gauge needle on ice. Cell extracts were precleared with $20 \mu$ l of protein A agarose beads to eliminate nonspecific binding. Supernatants were then incubated for $3 \mathrm{~h}$ with SMURF1, PAR6, GSK3 $\beta$, and PKC $\zeta$ antibodies at $4^{\circ} \mathrm{C}$ on a shaker. Twenty microliters of protein A agarose beads was then added, and the mixture was incubated on rotary mixer overnight at $4^{\circ} \mathrm{C}$. Beads and the associated immunoprecipitate were collected by centrifugation, washed once in PBS containing $0.5 \%(\mathrm{v} / \mathrm{v})$ Tween 20, 0.1\% (w/v) SDS, and then three times in PBS containing $0.5 \%(\mathrm{v} / \mathrm{v})$ Tween 20 and $0.5 \mathrm{M} \mathrm{NaCl}$. Pellets were resuspended in SDS-PAGE sample buffer [62.5 mm Tris, $\mathrm{pH}$ 6.8 , containing $2 \%(\mathrm{w} / \mathrm{v})$ SDS, $10 \%(\mathrm{v} / \mathrm{v})$ glycerol, $5 \%$ (v/v) $\beta$-mercaptoethanol, and $0.001 \%$ $(\mathrm{w} / \mathrm{v})$ bromophenol blue] and boiled for $5 \mathrm{~min}$. Immunoprecipitates were separated on polyacrylamide gels, and protein immunoblots were probed using antibodies (1:1000) against SMURF1, PAR6, GSK3 $\beta$, and PKC $\zeta$. Control immunoprecipitations were performed by omitting the primary antibody.

Organ culture analysis of neural crest migration. E11.5 C57BL/6 mouse gut explants containing stomach, small bowel, and colon were pinned to $2 \%$ agarose and cultured in $500 \mu \mathrm{l}$ (DMEM, 10\% fetal calf serum, and penicillin/ streptomycin) containing GSK3 $\beta$ inhibitors (5 $\mu \mathrm{M}$ SB216763 or $10 \mu \mathrm{M}$ SB415286) or PKC $\zeta$ inhibitor $(10 \mu \mathrm{M}$ myristoylated pseudosubstrate inhibitor). After $48 \mathrm{~h}\left(37^{\circ} \mathrm{C}, 5 \% \mathrm{CO}_{2}\right)$, tissues were fixed (4\% paraformaldehyde, 30 $\min , 25^{\circ} \mathrm{C}$ ) and then processed for wholemount immunohistochemistry using rabbit polyclonal TuJ1 (1:100) antibody.

GSK3 $\beta$ small interfering RNA studies. We used a small interfering RNA (siRNA) target sequence (GAACCGAGAGCTCCAGATC) that has been successfully used by several other investigators to silence GSK3 $\beta$ (Yu et al., 2003; Jiang et al., 2005; Yoshimura Scale bars, $50 \mu \mathrm{m}$.
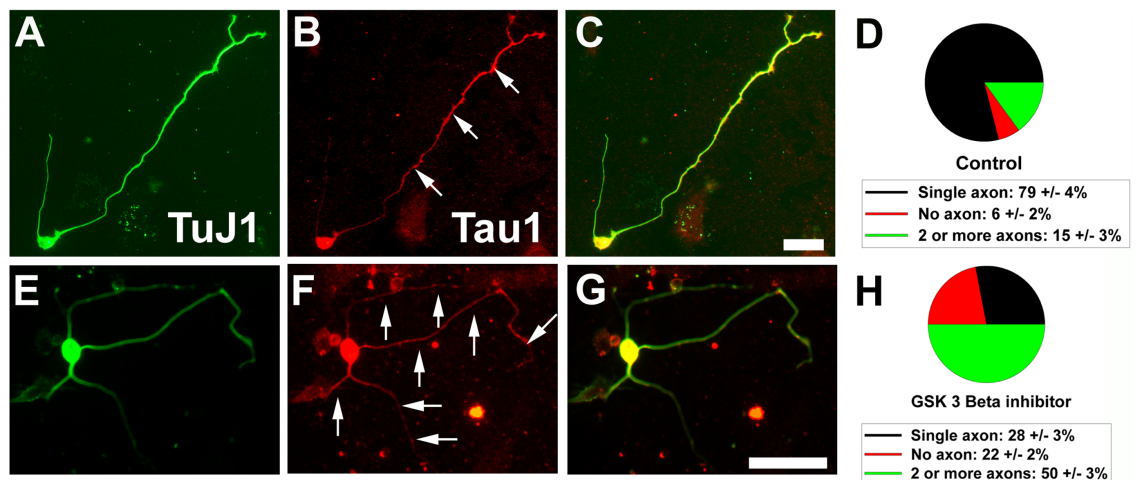

$\mathbf{H}$
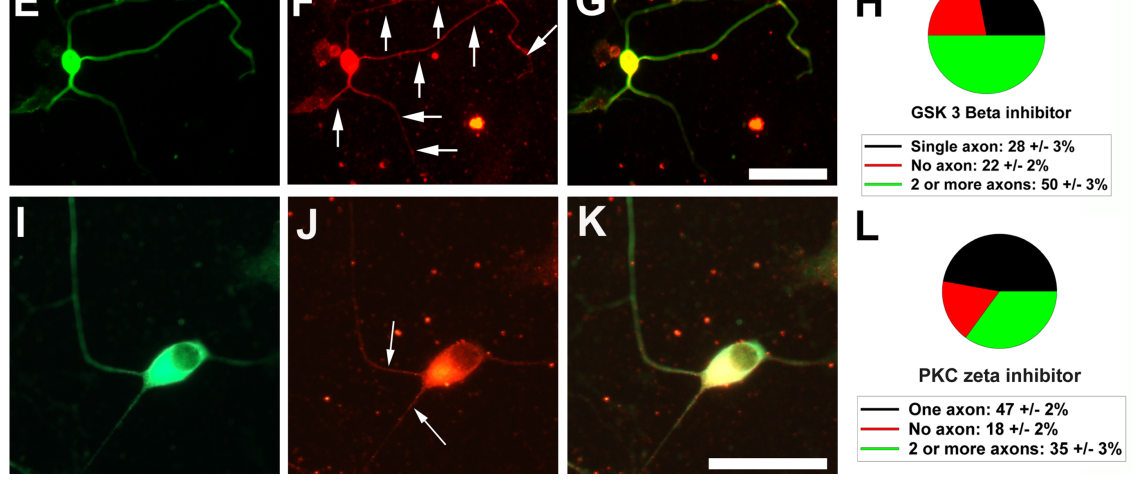

Figure 2. Inhibitors of PKC $\zeta$ or GSK3 $\beta$ increase the percentage of multi-axonal neurons and the percentage of neurons without axons. E14.5 rat immunoselected ENS precursors were maintained in culture for $48 \mathrm{~h}(\boldsymbol{A}-\boldsymbol{C})$ under control conditions, with a GSK3 $\beta$ inhibitor (SB216763) (E-G), or with a specific PKC $\zeta$ inhibitor (myristoylated pseudosubstrate inhibitor) $(\boldsymbol{I}-\boldsymbol{K})$. $\boldsymbol{A}, \boldsymbol{E}, \boldsymbol{I}$, Enteric neurons were identified with an antibody to neuron-specific $\beta$ III tubulin (TuJ1). Axons were identified with an antibody to TAU1 $(\boldsymbol{B}, \boldsymbol{F}, \boldsymbol{J})$. Arrows indicate TAU1-expressing neurites. Merged images are shown in $\boldsymbol{C}, \boldsymbol{G}$, and $\boldsymbol{K}$. Cells were classified based on the number of TAU1-expressing neurites present $(\boldsymbol{D}, \boldsymbol{H}, \boldsymbol{L})(n=125$ cells). Similar results were obtained with an alternate GSK3 $\beta$ inhibitor (SB415286). Scale bars, $50 \mu \mathrm{m}$.

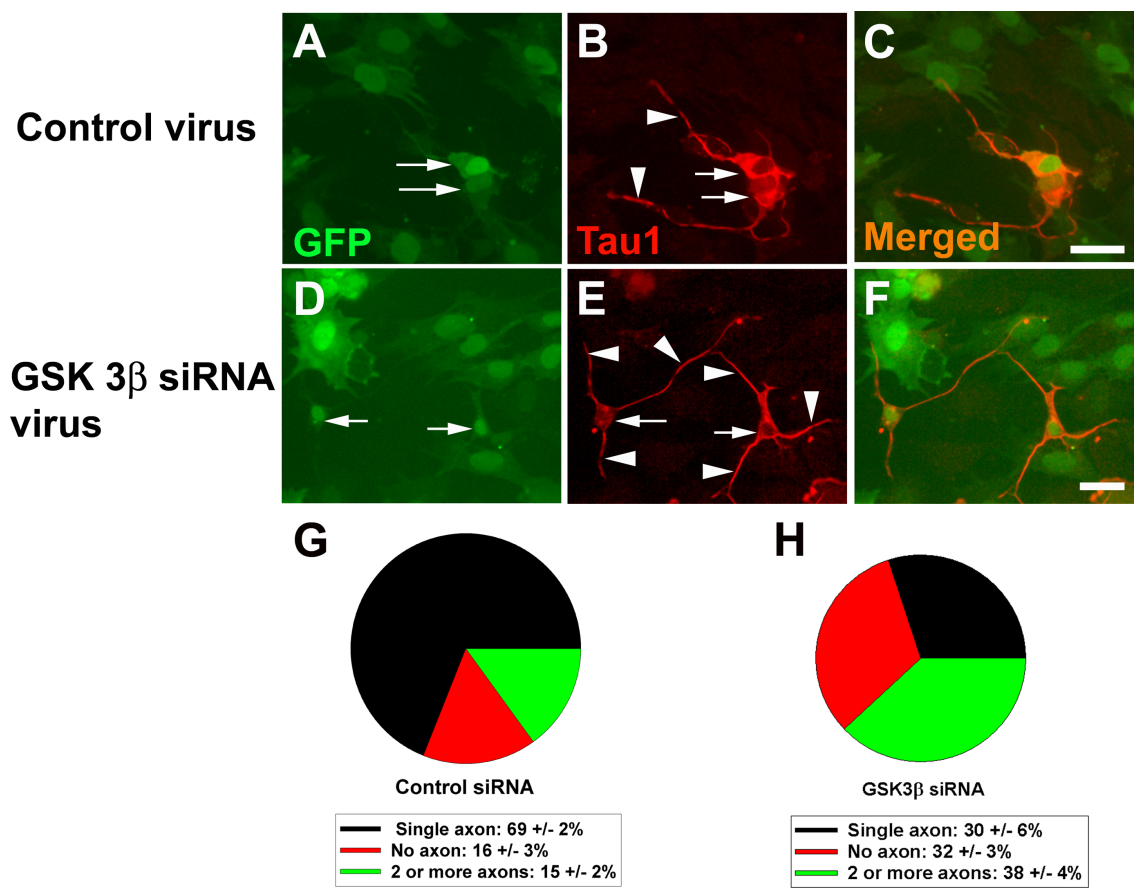

Figure 3. GSK3 $\beta$ siRNA increases the percentage of multi-axonal neurons and the percentage of neurons without axons. $\boldsymbol{A}-\boldsymbol{C}$, E12.5 mouse immunoselected ENS precursors infected with control virus $(\boldsymbol{A}-\boldsymbol{C})$ or GSK3 $\beta$ siRNA producing virus $(\boldsymbol{D}-\boldsymbol{F})$ were maintained in culture for $48 \mathrm{~h}$ after plating. $\boldsymbol{A}, \boldsymbol{C}, \boldsymbol{D}, \boldsymbol{F}$, The virus encodes GFP in addition to the siRNA so that infected cells are readily identified. In these experiments, all cells in the dish were infected and all TuJ1 ${ }^{+}$cells expressed TAU1 ${ }^{+} . \boldsymbol{B}, \boldsymbol{E}$, Immunohistochemistry was performed using an antibody to TAU1. C, $\boldsymbol{F}$, Merged images. $\mathbf{G}, \boldsymbol{H}$, Cells were classified based on the number of $\mathrm{TAU1}^{+}$neurites present $(n=159$ cells). Arrows indicate neuron cell bodies. Arrowheads indicate TAU1-expressing neurites.

et al., 2005; Kim et al., 2006). PAGE purified oligonucleotides (IDT, San Diego, CA) for the hairpin siRNA included sites for directional cloning (top strand, 5'ACCGAACCGAGAGCTCCAGATCTTCAAGAGAGATCTGGAGCTCTCGGTTCTTTTTC 3'; bottom strand, 5'TCGAGAAAAAGAAC- 

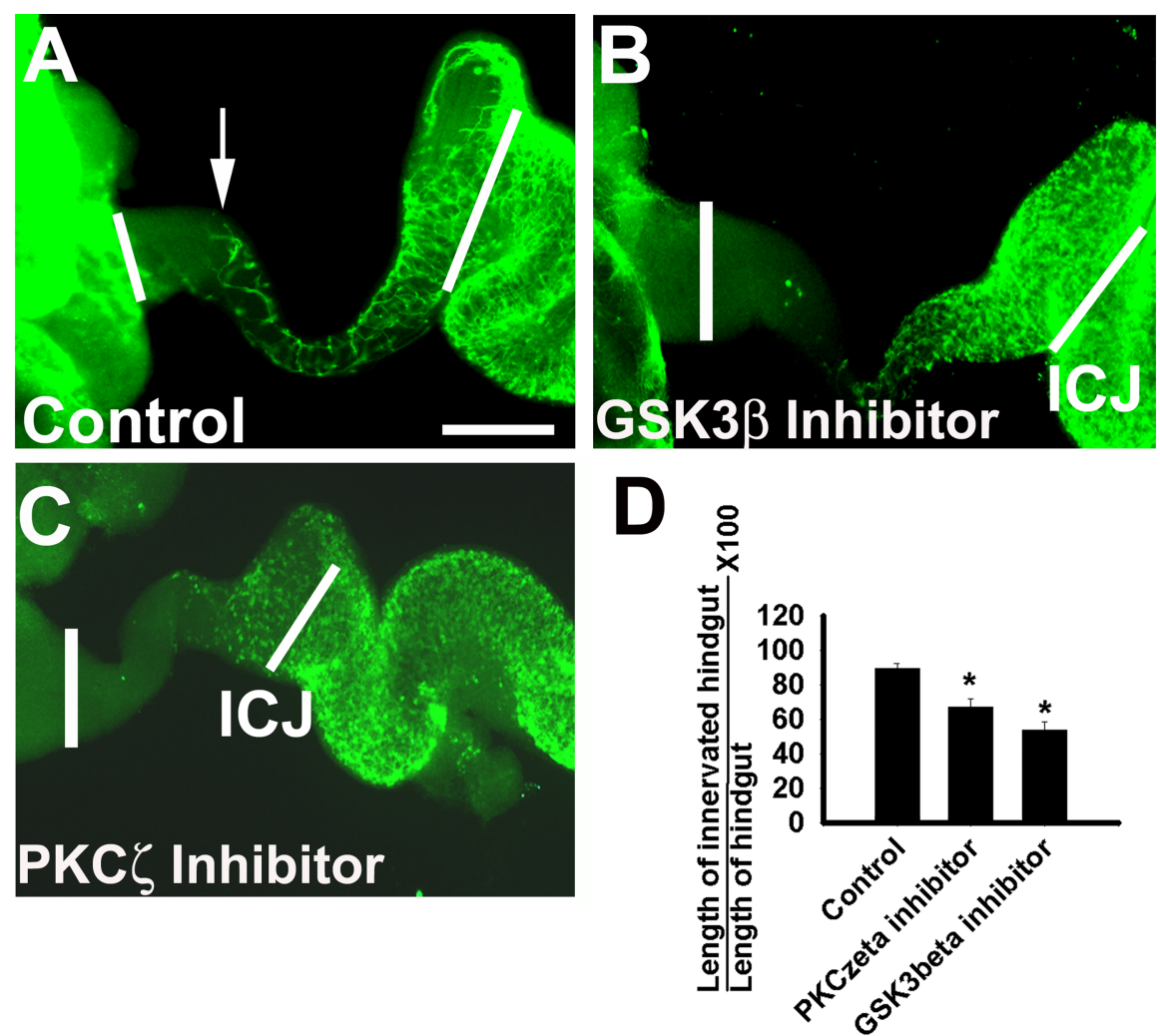

*Significantly different from control $(\mathrm{P}<0.002)$.

Figure 4. Inhibitors of PKC $\zeta$ or GSK3 $\beta$ reduce the rate of ENS precursor migration through the distal bowel. E11.5 mouse gut explants containing stomach, small bowel, and colon were cultured for $48 \mathrm{~h}$ in control medium $(A)$ or in medium containing GSK3 $\beta$ inhibitor (SB216763) (B) or PKC $\zeta$ inhibitor (myristoylated pseudosubstrate inhibitor) (C). At the start of the culture, ENS precursors had migrated to the ileocecal junction $(I C)$ and are about to enter the colon. $D$, Quantitative analysis of the percentage of the colon colonized by ENS precursors under different conditions. \% Colon colonization $=$ (distance from ICJ to wave front of migrating ENS precursors/distance from ICJ to the end of the colon) $\times 100 . n=5-8$ gut specimens were analyzed under each condition. Similar results were obtained with an alternate GSK3 $\beta$ inhibitor (SB415286). The white bar at the left edge of each image indicates the end of the colon. Arrow in $A$ indicates the leading edge of the wave front of migrating cells. Scale bar, $50 \mu \mathrm{m}$.

CGAGAGCTCCAGATCTCTCTTGAAGATCTGGAGCTCTCGGTTC 3') and were annealed before ligation into BbsI and XhoI sites immediately downstream of the U6 promoter in the $\mathrm{pBS}-\mathrm{hU} 6$ vector. The siRNA expression cassette from pBS-hU6 vector was then subcloned into the FG12 lentiviral vector between the $\mathrm{XbaI}$ and $\mathrm{XhoI}$ sites, and lentivirus was generated as described previously (Qin et al., 2003). Complementary oligonucleotide pairs for the control siRNA sequence (CAGTCGCGTTTGCGACTGG) were as follows: top strand, 5'ACCG G C A G T C G C G T T T G C G A C T G G T T C A A G A G A CCAGTCGCAAACGCGACTGTTTTTTCTTTTTC 3'; bottom strand, 5'TCGAGAAAAAGAAAAAACAGTCGCGTTTGCGACTGGTCTCTTGAACCAGTCGCAAACGCGACTGC $3^{\prime}$.

Smurf1 siRNA studies. The Smurf1 siRNA target sequence (CCGACACTGTGAAAAACAC) (Wang et al., 2003) was cloned into RNAiReady pSiren-RetroQ-ZsGreen vector, which expresses a reef coral green fluorescent protein (ZsGreen) (BD Biosciences) by adding BamH1 and $E c o R 1$ sites to enable directional cloning. An Mlu1 site was inserted to facilitate plasmid identification. PAGE purified oligonucleotides (IDT) for the hairpin siRNA were as follows: top strand, $5^{\prime}$ gatccGCCGACACTGTGAAAAACACTTCAAGAGAGTGTTTTTCACAGTGTCGGTTTTTTACGCGTG 3'; bottom strand, 5' aattcACGCGTAA A A A A C C G A C A C T G T G A A A AACACTCTCTTGAAGTGTTTTTCACAGTGTCGGCg 3'. Complementary oligonucleotide pairs for the control siRNA sequence (CAGTCGCGTTTGCGACTGG) were as follows: top strand, 5' gatccGCAGTCGCGTTTGCGACTGGTTCAAGAGACCAGTCGCAAACGCGACTGGTTTTTTTACGCGTg3'; bottom strand, 5'aattcACGCGTAAAAAACAGTCGCGTTTGCGACTGGTCTCTTGAACCAGTCGCAAACGCGACTGCg3'.

Smurf1 siRNA virus production. To produce retrovirus for Smurf1
siRNA, GP2-293 cells (BD Biosciences) $(1 \times$ $10^{6}$ ) grown on a $60 \mathrm{~mm}$ dish were cotransfected $12 \mathrm{~h}$ after plating with pSiren-RetroQ-ZsGreen vectors ( $5 \mu \mathrm{g}$; BD Biosciences) and a viral coat protein plasmid (pVSV-G) $(5 \mu \mathrm{g}$; BD Biosciences) using Fugene 6 (Roche Diagnostics, Indianapolis, IN). Culture medium was replaced $6 \mathrm{~h}$ after transfection with $3 \mathrm{ml}$ of new medium [DMEM with glutamine $/ 10 \%$ fetal calf serum (Hyclone, Logan, UT)]. Viral particles were harvested from culture medium $72 \mathrm{~h}$ after transfection by centrifuging to eliminate cell debris $\left(500 \times g, 10 \mathrm{~min}, 4^{\circ} \mathrm{C}\right)$ and then by ultracentrifugation $\left(50,000 \times g, 90 \mathrm{~min}, 4^{\circ} \mathrm{C}\right)$. Viral pellet was resuspended in $50 \mu$ l of PBS. Viral titer was $4 \times 10^{4} \mathrm{pfu} / \mu \mathrm{l}$.

Viral infection studies. Enteric neural crestderived cells from E12.5 CF1 mice were immunoselected from the small bowel and colon as described above and plated on fibronectin (250 $\mu \mathrm{g} / \mathrm{ml}$; Invitrogen) coated four-well Permanox Sonic Seal chamber slides (Nalge Nunc, Woburn, MA). Cells were grown in DMEM plus $10 \%$ chick embryo extract (SLI, Bolney, West Sussex, UK). Three hour after plating, cells were infected with virus expressing Smurf1 siRNA, GSK3 $\beta$ siRNA, or control siRNAs by adding $10-20 \mu \mathrm{l}$ of the viral solution. Medium was changed $12 \mathrm{~h}$ after infection. Infection was confirmed by ZsGreen expression in cells infected with Smurf1 siRNA and control virus and by green fluorescent protein (GFP) expression in cells infected with GSK3 $\beta$ siRNA and control virus. After $2 \mathrm{~d}$ in culture, cells were trypsinized and replated (10,000 cells per well) on fibronectin $(250 \mu \mathrm{g} / \mathrm{ml}$; Invitrogen $)$ coated four-well Permanox Sonic Seal chamber slides (Nalge Nunc) and grown in DMEM plus $10 \%$ chick embryo extract and GDNF (50 ng/ml; PeproTech, Rocky Hill, NJ). For the ROCK inhibitor studies, ROCK inhibitors ( $10 \mu \mathrm{M}$ Y-27632 or 10 nм H-1152P) were added at the time of plating. Cells were maintained in a humidified environment $\left(5 \% \mathrm{CO}_{2}, 37^{\circ} \mathrm{C}\right)$ for $48 \mathrm{~h}$ before washing with PBS and fixing $(4 \%$ paraformaldehyde, $20 \mathrm{~min}, 25^{\circ} \mathrm{C}$ ) for immunohistochemical analysis. All experiments were performed in triplicate.

Protein immunoblot to evaluate effectiveness of SB216763 and Smurf1 siRNA. TAU1 and TAUpS396 (pTAU1) protein immunoblotting was performed on the immunoselected enteric neural crest from E14.5 Sprague Dawley rat. Cells were maintained in culture with or without 5 $\mu \mathrm{M}$ GSK3 $\beta$ inhibitor (SB216763) as described above for $48 \mathrm{~h}$ (supplemental Fig. 1, available at www.jneurosci.org as supplemental material). SMURF1 and RhoA protein levels were analyzed in cultured immunoselected enteric neurons that were maintained in culture and infected with control virus or Smurf1 siRNA virus as described above. Cultured cells were lysed with M-per mammalian protein extraction reagent (Pierce, Rockford, IL) supplemented with protease inhibitor cocktail (Roche, Penzberg, Germany) and Halt phosphatase inhibitor cocktail (Pierce). Twenty micrograms of protein were subjected to electrophoresis on $4-12 \%$ Tris-glycine SDS-PAGE gradient gels (Invitrogen). Proteins were transferred to nitrocellulose membranes (GE Healthcare, Little Chalfont, UK) before the membranes were probed with the antibodies for TAU1, P-TAU1, SMURF1, and RhoA and developed using Amersham ECL Western blotting detection reagents (GE Healthcare). The films were scanned, and band densities were analyzed using NIH ImageJ 1.30 software.

Statistical analyses. Statistical analysis was performed using SigmaStat software (Systat Software, San Jose, CA), and either $t$ test or Mann- 
Whitney rank sum test were used. Data are presented as mean \pm SE. $p<0.05$ is considered significant.

\section{Results}

Developing enteric neurons express proteins that control polarization in other cell types

E14.5 rat enteric neuron precursors immunoselected with an antibody to $\mathrm{p} 75^{\text {NTR }}$ and maintained in culture were analyzed for the expression of PAR3, PAR6, phospho-PKC $\zeta$, and phospho-GSK3 $\beta$ by immunohistochemistry because localization of these proteins influences cell polarity and neurite specification in other cell types. Analyses were limited to cells that had clearly begun to differentiate into neurons based on the expression of neuronal class III $\beta$-tubulin $\left(\mathrm{TuJ} 1^{+}\right)$, which is present in all neurites, and Tau1, a marker for axons. At this stage in development, some ENS precursors are still actively proliferating, but others are differentiating into a variety of enteric neuron subtypes (Barlow et al., 2003; Vohra et al., 2006). PAR3, PAR6, p-PKC $\zeta$, and p-GSK3 $\beta$ had a similar distribution at each time point. Immunohistochemistry performed $24 \mathrm{~h}$ after plating ENS precursors demonstrated that PAR3, PAR6, p-PKC $\zeta$, and p-GSK $3 \beta$ were highly expressed throughout the cell body and the longest axon in approximately half of all developing enteric neurons (e.g., for PAR3, this distribution occurred in $48 \pm 8 \%$ of TAU $1^{+}$cells). After $48 \mathrm{~h}$ in culture PAR3, p-PKC $\zeta$, and p-GSK3 $\beta$ were more highly abundant at the tip of TAU1 ${ }^{+}$axons than along the axon shaft $\left(79 \pm 5 \%\right.$ of TAU1 ${ }^{+}$cells had this distribution for PAR3) (Fig. 1). In contrast, PAR6 was distributed uniformly along the axon shaft and tip (Fig. $1 E-H$ ). Each of these proteins was also abundant in the cell body at 24 and $48 \mathrm{~h}$ after plating. After $3 \mathrm{~d}$ in culture, most of the immunoreactivity of these proteins that control cell polarity localized to the cell body of the enteric neurons $\left(92 \pm 3 \%\right.$ of TAU1 ${ }^{+}$cells had this distribution for PAR3; $n=200$ neurons analyzed for each time point). These changes in polarity protein localization are similar to those seen in hippocampal neurons and suggest this protein complex determines neurite polarity in the developing ENS.

\section{Neuronal polarization requires PKC $\zeta$ and GSK3 $\beta$}

Although enteric neurons are not a uniform population, rat enteric neuroblasts develop into neurons with a single long axon, or multiple axons over $48 \mathrm{~h}$ in culture in reproducible ratios that allow us to investigate the role of PKC $\zeta$, GSK3 $\beta$, and other proteins in axon specification. For example, when immunoselected (i.e., p75 ${ }^{\text {NTR }}$ expressing) E14.5 rat ENS precursors are cultured under control conditions, $79 \pm 4 \%$ of $\mathrm{TuJ} 1^{+}$cells have a single $\mathrm{TAU}^{+}$axon, $15 \pm 3 \%$ have two or more axons, and $6 \pm 2 \%$ have no TAU1 ${ }^{+}$processes (Fig. $2 A-D$ ). To determine whether GSK3 $\beta$ influences enteric neuron polarity, GSK3 $\beta$ activity was blocked
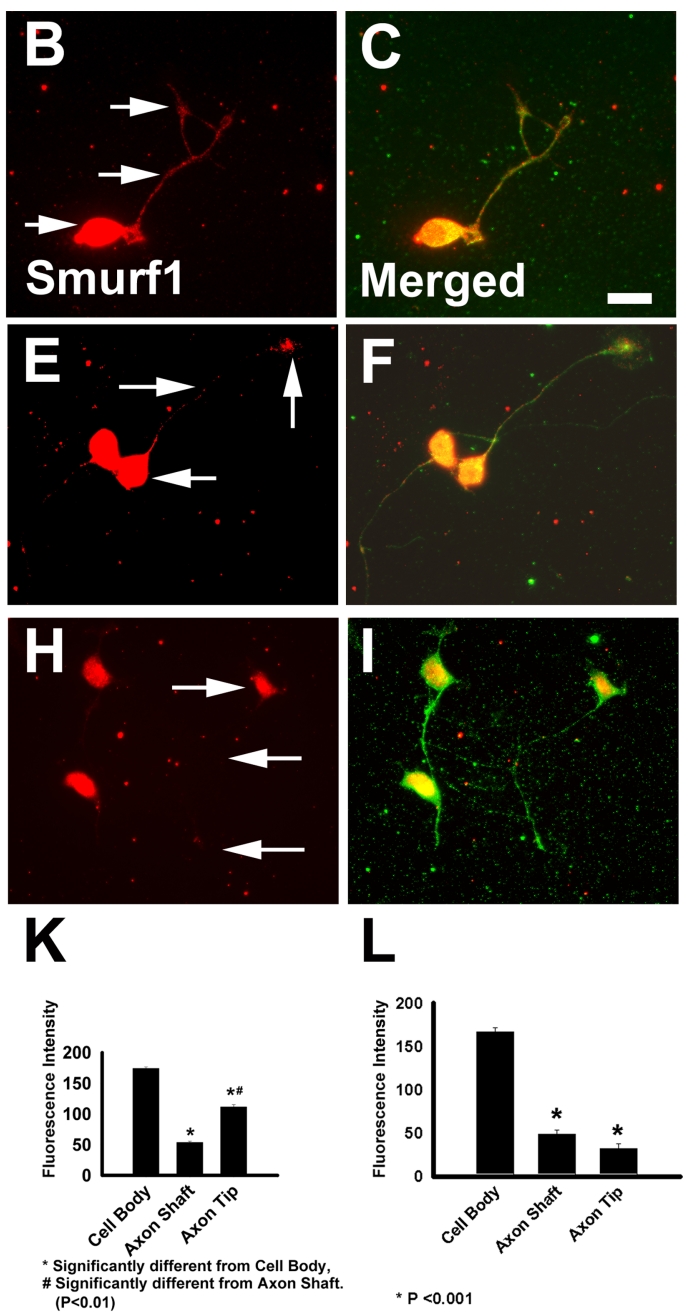

Significantly different from Axon Shatt. $\quad * \quad * 0<0.001$

Figure 5. SMURF1 protein is expressed in a polarized distribution in enteric neuron precursors. E14.5 rat immunoselected ENS precursors were maintained in culture for 24,48 , or $72 \mathrm{~h}$ before immunohistochemistry with an antibody to TAU1 $(A, D, G)$ or and axon tip was determined after $24 \mathrm{~h}(\boldsymbol{J}), 48 \mathrm{~h}(\boldsymbol{K})$, or $72 \mathrm{~h}(\boldsymbol{L})$ in culture. Arrows indicate the location of fluorescence intensity measurements. $n=25$ cells analyzed for each time point. Scale bar, $50 \mu \mathrm{m}$.

throughout the cell using either of two different inhibitors $(5 \mu \mathrm{M}$ SB216763 or $10 \mu \mathrm{M}$ SB415286). This caused a dramatic increase in the percentage of developing ENS precursors with multiple TAU $1^{+}$axons (Fig. $2 E-H$ ). Specifically, GSK3 $\beta$ inhibition caused a 3.3-fold increase $(p<0.001)$ in $\mathrm{TuJ1}{ }^{+}$cells with multiple axons and a 3.7-fold increase $(p<0.01)$ in the number of cells with no axons (Fig. $2 H$ ). Similarly, infection of ENS precursors with a lentivirus expressing siRNA that efficiently silences GSK3 $\beta$ expression (supplemental Fig. 2, available at www. jneurosci.org as supplemental material) resulted in a 2.5 -fold increase $(p<0.001)$ in the number of enteric neurons with multiple TAU ${ }^{+}$axons and a twofold increase $(p<0.001)$ in the number of cells with no axon (Fig. 3). Thus, global inhibition of GSK3 $\beta$ increases the percentage of developing enteric neurons with multiple $\mathrm{TAU} 1{ }^{+}$neurites.

PKC $\zeta$ interacts with GSK $3 \beta$ and influences cell polarization in several other contexts (Lin et al., 2000; Etienne-Manneville and Hall, 2001, 2003a; Wang et al., 2003; Higginbotham et al., 2006). To determine whether PKC $\zeta$ activity is important for neurite specification (axon vs dendrite) in ENS precursors, we used chemical inhibitors to globally block PKC $\zeta$ activity. Unlike results in hippocampal neurons in which PKC inhibition results in 


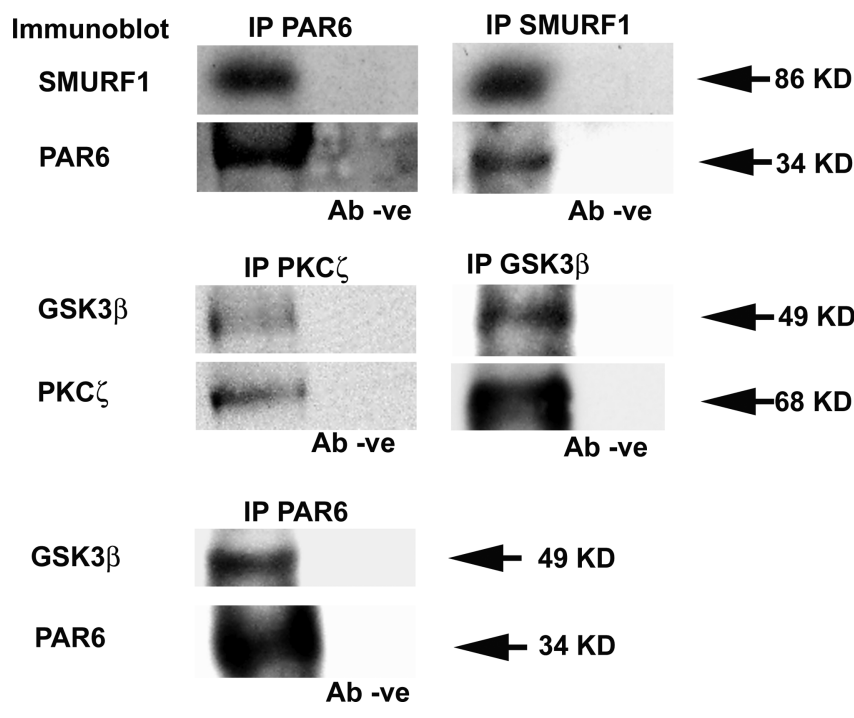

Figure 6. PAR6, GSK3 $\beta$, PKC $\zeta$, and SMURF1 proteins coimmunoprecipitate. Cell lysates prepared from p $75^{\text {NTR }+}$ immunoselected cells were immunoprecipitated (IP) using antibodies to SMURF1, PAR6, GSK3 $\beta$, and PKC $\zeta$. Immunoprecipitates were separated by SDS-PAGE, and protein immunoblots were incubated with antibodies against SMURF1, PAR6, GSK3 $\beta$, and PKC $\zeta$ as indicated. Blank lanes on the gel were from immunoprecipitations performed with the primary antibody omitted (Ab - ve).

loss of axons (Shi et al., 2003), inhibition of PKC activity in ENS precursors using a general PKC inhibitor ( $50 \mathrm{~nm}$ bisindolylmaleimide) resulted in both a 2.1 -fold $(p<0.01)$ increase in the number of cells with multiple Tau1 ${ }^{+}$axons and a 4.5 -fold $(p<$ 0.001 ) increase in the number of cells with no axons. Similarly, inhibition of PKC $\zeta$ using a specific PKC $\zeta$ inhibitor (10 $\mu \mathrm{M}$ myristoylated pseudosubstrate inhibitor selective for $\mathrm{PKC} \zeta$ ) caused a substantial increases in the number of cells with multiple Tau ${ }^{+}$ axons (2.3-fold; $p<0.01$ ) or without axons (3.0-fold; $p<0.01$ ) (Fig. $2 I-L)$. To confirm that these effects on axon number in ENS precursors were not influenced by effects of these inhibitors on cell survival, we counted the total number of Ret ${ }^{+}$cells per well. None of the inhibitors used had any effect on Ret $^{+}$cell number, suggesting that the inhibitors are not inducing cell death (control, $323 \pm 30$ Ret $^{+}$cells per well; SB216763,318 \pm 13 Ret $^{+}$cells per well; SB415286, $304 \pm 10 \mathrm{Ret}^{+}$cells per well; bisindolylmaleimide, $333 \pm 38 \mathrm{Ret}^{+}$cells per well; PKC $\zeta$ inhibitor, $355 \pm 33 \mathrm{Ret}^{+}$ cells per well). Thus, global inhibition of either GSK3 $\beta$ or PKC $\zeta$ activity influences neuronal polarization of cultured enteric neuroblasts, resulting in an increase in multi-axonal cells and an increase in cells without axons.

PKC $\zeta$ and GSK $3 \beta$ are required for neural crest migration into the distal bowel

Directed migration of ENS precursors also presumably requires polarization of the migrating cells. Because vagal neural crest derivatives that form the ENS have one of the longest migratory routes of any cell in the body during development, we hypothesized that ENS precursor migration would require some of the same molecular machinery used for neurite polarization. To test the hypothesis that PKC $\zeta$ and GSK3 $\beta$ are important for ENS precursor migration, mouse E11.5 gut was maintained in organ culture for $48 \mathrm{~h}$ in the presence of PKC $\zeta$ or GSK3 $\beta$ inhibitors. At the start of the culture, ENS precursors that migrate from the vagal crest through the bowel to the end of the colon had just reached the ileocecal junction. In the control cultures, $89 \pm 3 \%$ of the colon was populated by ENS precursors after $48 \mathrm{~h}$ in culture. In contrast, treatment with the PKC $\zeta$ inhibitor reduced colon innervation to $67 \pm 4 \%$. GSK3 $\beta$

\section{Control virus SIRNA virus}
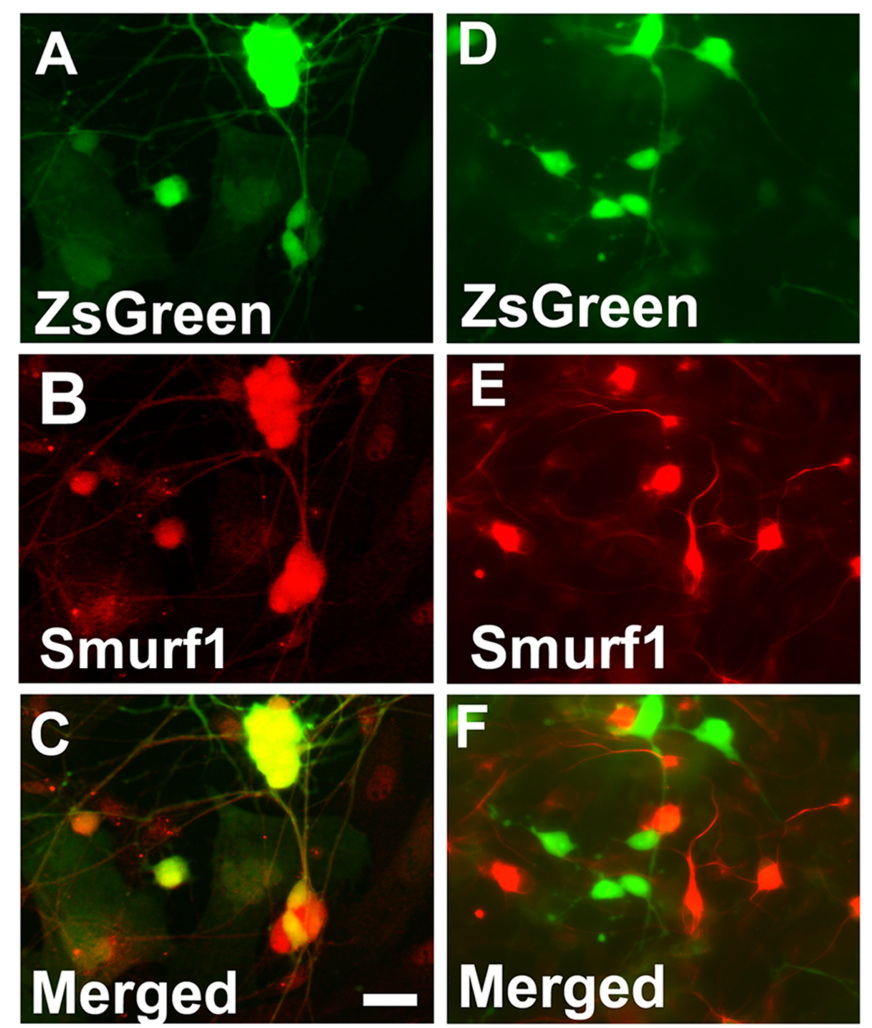

G
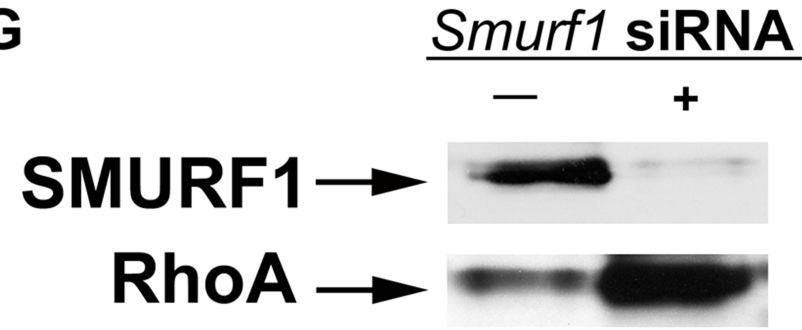

\section{GAPDH $\rightarrow$}

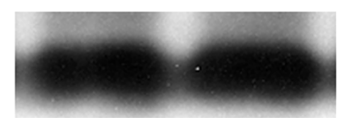

Figure 7. Smurf1 siRNA-expressing virus efficiently reduces SMURF1 protein levels and results in RhoA protein accumulation. E12.5 mouse immunoselected ENS precursors infected with control virus $(\boldsymbol{A}-\boldsymbol{C})$ or Smurf1 siRNA producing virus $(\boldsymbol{D}-\boldsymbol{F})$ were maintained in culture for $48 \mathrm{~h}$ after plating. $A, D$, The virus encodes $Z s G$ reen in addition to the siRNA so that infected cells are readily identified. Immunohistochemistry was performed using an antibody to SMURF1 $(\boldsymbol{B}, \boldsymbol{E})$ and demonstrates that SMURF1 protein is not detected in cells infected with Smurf1 siRNA producing virus. $C, F$, Merged images. $G$, Protein immunoblot of cells infected with control virus or Smurf1 siRNA virus. The Smurf1 siRNA efficiently reduces SMURF1 protein levels and causes increased RhoA accumulation.

inhibitors also reduced colon innervation to $54 \pm 4 \%$ of total colon length. These data confirm an important role for PKC $\zeta$ and GSK3 $\beta$ in ENS precursor migration (Fig. 4).

Polarized distribution of SMURF1 in enteric neurons Recent work in other systems has suggested that PKC $\zeta$-induced changes in cell polarity can be mediated by recruitment of the E3 ubiquitin ligase SMURF1 to cellular protrusions (Wang et al., 2003). SMURF1 then locally degrades RhoA, which in turn regulates actin cytoskeletal dynamics. We therefore hypothesized that SMURF1 might critically regulate neuronal polarity in de- 
veloping enteric neuroblasts. To test this hypothesis, we first demonstrated by immunohistochemistry that SMURF1 was expressed in ENS precursors (Fig. 5). Remarkably, the immunohistochemical staining pattern for SMURF1 in enteric neuroblasts after 24,48 , or $72 \mathrm{~h}$ in culture was very similar to the distribution of PAR3, PKC $\zeta$, and GSK3 $\beta$. Specifically, double-label immunohistochemistry for TAU1 and SMURF1 demonstrated SMURF1 immunoreactivity in the cell body and axonal processes after $24 \mathrm{~h}$ in culture (Fig. $5 A-C, J$ ). By day 2 in culture, SMURF1 immunoreactivity was more restricted to the cell body and the tip of the growing axon with reduced immunoreactivity in the axon shaft (Fig. 5D-F,K). By the third day in culture, SMURF1 was primarily confined to the cell body of the enteric neurons with very low levels in axons (Fig. 5G-I,L).

SMURF1, PKC $\zeta$, and GSK3 $\beta$ associate with PAR6 in enteric neuroblasts The similar distribution of SMURF1, $\mathrm{PKC} \zeta$, GSK $3 \beta$, and PAR3 proteins in developing enteric neuroblasts suggested the possibility that all of these proteins associate with each other in developing ENS precursors. PKC $\zeta$, GSK3 $\beta$, PAR6, and PAR3 are already known to associate in other cell types in which this interaction is important for cell polarization (Lin et al., 2000; Etienne-Manneville and Hall, 2003b). PKC $\zeta$ and SMURF1 also are known to interact directly in vitro in $\mathrm{Mv} 1 \mathrm{Lu}$ and NIH3T3 cells (Wang et al., 2003). To test the hypothesis that SMURF1 associates with other proteins involved in cell polarity in ENS precursors, we performed coimmunoprecipitation experiments and protein immunoblotting (Fig. 6). These analyses confirmed that GSK3 $\beta$ coimmunoprecipitates with both PAR6 and PKC $\zeta$ from immunoselected ENS precursors and that SMURF1 and PAR6 coimmunoprecipitate with each other. Thus, SMURF1 in ENS precursors associates with the complex of proteins that controls cell polarity.

SMURF1 is required for neurite formation and elongation in ENS precursors

Because SMURF1 degrades RhoA (Wang et al., 2006) and RhoA inhibits axon growth (Bryan et al., 2005), we initially hypothesized that blocking Smurf1 would reduce neurite length in cultured ENS precursors. To test this hypothesis, E12.5 immunoselected ENS precursors were infected with a retrovirus that produces siRNA to block SMURF1 production (Fig. 7). The virus also produces ZsGreen so that infected cells can be easily identified. ENS precursors were initially maintained in media with chick embryo extract but without additional GDNF for $48 \mathrm{~h}$ to allow for siRNA production. Neurospheres formed under these conditions were trypsinized and replated in GDNF-containing medium to encourage neuronal differentiation and neurite growth. Analysis of the infected cells by SMURF1 immunohistochemistry and ZsGreen fluorescence after
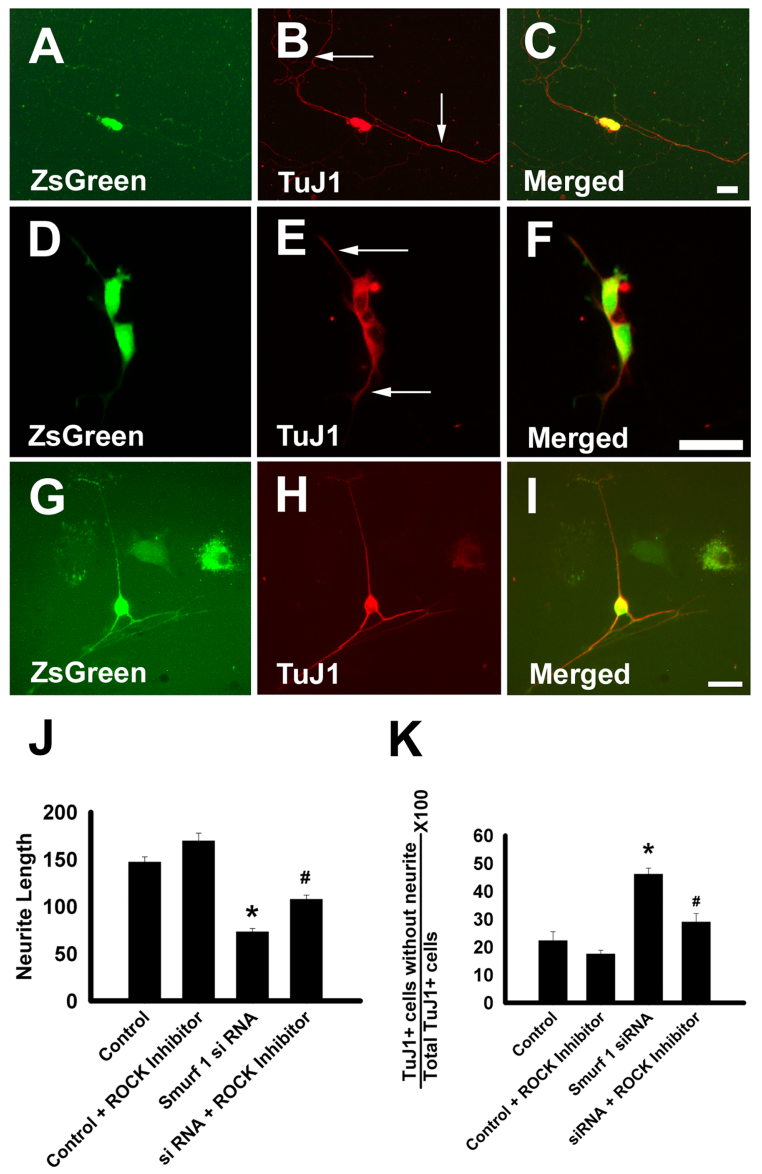

Figure 8. Smurf1 siRNA reduces neurite length and increases the percentage of neurons without neurites. E12.5 mouse immunoselected ENS precursors infected with control virus $(\boldsymbol{A}-\boldsymbol{C})$ or Smurf1 siRNA producing virus $(\boldsymbol{D}-\boldsymbol{F})$ were maintained in culture for $48 \mathrm{~h}$ after plating. $\boldsymbol{A}, \boldsymbol{D}, \boldsymbol{G}, \mathrm{Zs}$ Green expression identifies virus-infected cells. $\boldsymbol{B}, \boldsymbol{E}, \boldsymbol{H}$, Immunohistochemistry with TuJ1 , Merged images. G-I, Cells expressing Smurf1 siRNA were cultured in the presence of a ROCK inhibitor (10 $\mu \mathrm{M}$ ( $n=132$ cells) or of the percentage of cells with no neurites $(n=316$ cells). Arrows indicate Tus um. ${ }^{*} p<0.001$, significantly different from control. ${ }^{*} p<0.001$, significantly different from Smurf1

an additional $48 \mathrm{~h}$ in culture demonstrated that Smurf1 siRNA virusinfected cells had essentially no detectable SMURF1 immunoreactivity (Fig. 7D-F), whereas SMURF1 was readily detected in cells infected with a control retrovirus (Fig. 7A-C). The effectiveness of Smurf1 siRNA was also confirmed by protein immunoblot analysis (Fig. 7G), which demonstrated a 90\% loss of SMURF1 in infected cells $(p<0.001)$. Furthermore, Smurf1 siRNA virus-infected TuJ1 ${ }^{+}$ ENS precursors had significantly reduced neurite length compared with cells infected with control virus (Fig. $8 A-F, J$ ), and a high percentage of these cells failed to produce neurites during the culture period (Fig. $8 \mathrm{~K}$ ). These data suggested that blocking SMURF1 production significantly impairs neurite formation in ENS precursors.

Because SMURF1 is known to target RhoA for ubiquitin/ proteasome-mediated degradation, we hypothesized that the reduced neurite growth in Smurf1 siRNA-expressing virus-infected cells was attributable to increased RhoA activity. We demonstrated directly that RhoA protein is elevated 2.3-fold in ENS precursors infected with a virus producing Smurf1 siRNA by protein immunoblot analysis (Fig. $7 G)(p<0.001)$. We then tested the hypothesis that Smurf1 siRNA effects on neurite growth could be reversed by blocking the RhoA action, using an inhibitor of Rho kinase (ROCK), a downstream mediator of RhoA activity important for axon outgrowth in cerebellar granule cells (Bito et 
A

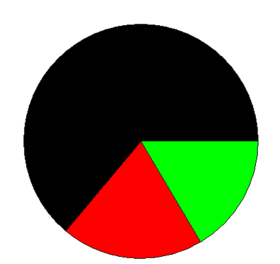

Control siRNA

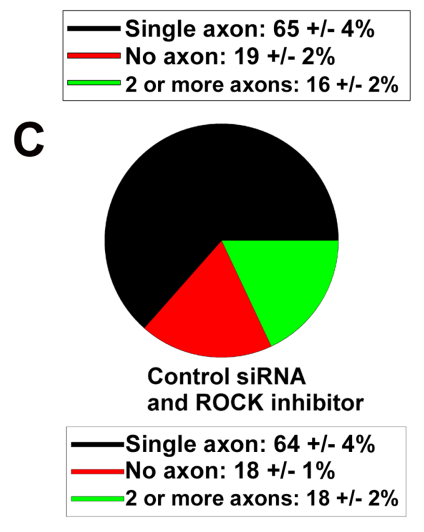

E

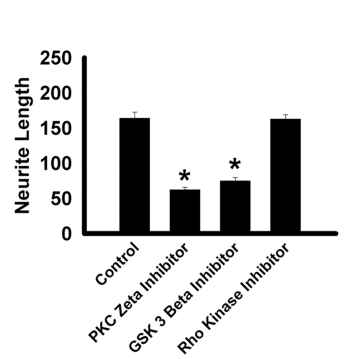

B

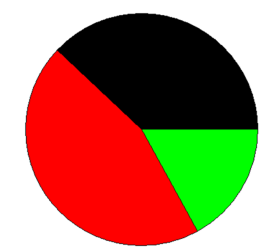

Smurf1 siRNA

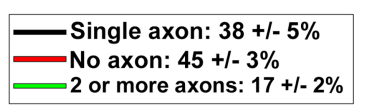

D

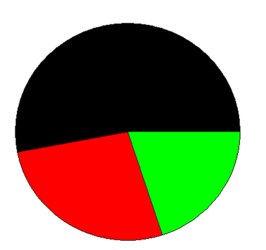

Smurf1 siRNA and ROCK inhibitor

-Single axon: $56+/-4 \%$ No axon: $24+1-2 \%$ 2 or more axons: $20+1-2 \%$
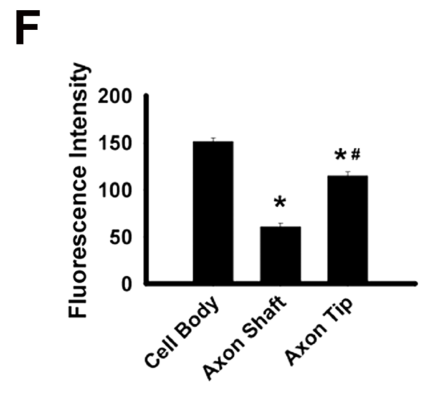

Figure 9. Smurf1 siRNA increases the percentage of cells with no axon but does not increase the percentage of cells with multiple axons. $\boldsymbol{A}-\boldsymbol{D}$, siRNA-expressing virus-infected E12.5 immunoselected mouse ENS precursors were cultured for $48 \mathrm{~h}$ after plating before staining with an antibody to TAU1 and a TuJ1 antibody. C, D, ROCK inhibitor used was Y-27632. A-D, Quantitative analysis of the number of axons per neuron under each condition $(n>289$ cells for each graph). $\boldsymbol{E}$, Quantitative analysis of the length of the longest neurite in each cell ( $n=120$ cells under each condition). The GSK3 $\beta$ inhibitor used was SB216763, the PKC $\zeta$ inhibitor used was the myristoylated pseudosubstrate inhibitor, and the ROCK inhibitor used was Y-27632. Similar results were obtained using alternate inhibitors H-1152P (ROCK inhibitor) and SB415286 (GSK3 $\beta$ inhibitor). $\boldsymbol{E}_{,}^{*} p<0.001$, significantly different from control. $\boldsymbol{F}$, Eliminating SMURF1 does not alter PAR3 polarization ( $n=34$ cells). $\boldsymbol{F},{ }^{*} p<0.001$, significantly different from cell body; ${ }^{\#} p<0.001$, significantly different from axon shaft.

al., 2000). These studies demonstrated that the inhibition of neurite growth induced by Smurf1 siRNA was at least partially reversed by ROCK inhibitor (Fig. $8 G-K$ ), consistent with the hypothesis that increased RhoA activity limits neurite growth when SMURF1 protein is absent. Interestingly, however, ROCK inhibitor had no effect on neurite length or on the presence of neurites in control siRNA-infected $\mathrm{TuJ1}{ }^{+}$cells. Together, these results suggest that SMURF1 normally essentially eliminates RhoA/ ROCK activity from the tips of growing neurites and that targeting RhoA for degradation is important for neurite growth in ENS precursors.

SMURF1 or ROCK inhibition have different effects on axon specification than PKC $\zeta$ or GSK3 $\beta$ inhibition

Because PKC $\zeta$, GSK3 $\beta$, and SMURF1 have a similar distribution in ENS precursors and appear to be in the same complex, we had hypothesized that reducing SMURF1 would affect neuronal polarity in the same way as PKC $\zeta$ or GSK3 $\beta$ inhibition. Specifically, we wanted to determine whether Smurf1 siRNA expression would lead to an increase in the generation of multi-axonal neurons that developed from cultured enteric neuroblasts. To test this hypothesis, immunoselected E12.5 ENS precursors were infected with retroviruses expressing Smurf1 siRNA or a control siRNA and maintained for $48 \mathrm{~h}$ in media with chick embryo extract but without added GDNF. Cells were then trypsinized, replated, and cultured in GDNF containing media to induce neurite growth and neuronal differentiation. The number of axons/ $\mathrm{TuJ1}^{+}$cell was evaluated after immunohistochemistry for TAU1. This analysis confirmed that Smurf1 siRNA expression reduced the number of $\mathrm{TuJ1}{ }^{+}$cells with a single axon and increased the number of neurons without any axons (Fig. $9 A, B$ ). In contrast to the results of PKC $\zeta$ or GSK3 $\beta$ inhibition, however, there was no significant increase in the percentage of $\mathrm{TuJ}^{+}{ }^{+}$cells with multiple axons despite the fact that blocking PKC $\zeta$, GSK3 $\beta$, or Smurf1 caused comparable reductions in neurite length (Figs. 8J, 9E). Furthermore, treatment of cells infected with Smurf1 siRNA producing virus with a ROCK inhibitor significantly reduced the number of TuJ1 ${ }^{+}$cells with no axon and increased the percentage of cells with a single axon but had minimal effect on the number on enteric neurons with multiple axons (Fig. 9C,D). These data suggest that, although SMURF1 associates with PAR3, PAR6, $\mathrm{PKC} \zeta$, and GSK $3 \beta$ in ENS precursors and is important for axon growth, SMURF1 does not influence neuronal polarization or axon specification. Consistent with this finding, Smurf1 inhibition also does not influence the polarized distribution of PAR3 protein in these cells (Fig. 9F).

\section{Discussion}

Axon specification is important for the neuronal differentiation. This type of polarized neurite specification is mediated by a protein complex including PKC $\zeta$, GSK3 $\beta$, PAR3, and PAR6 (Wiggin et al., 2005; Yoshimura et al., 2006). Each of these proteins has a demonstrated role in cell polarity in a number of contexts (Wodarz, 2002; Etienne-Manneville and Hall, 2003a). The current study demonstrates that PKC $\zeta$, GSK3 $\beta$, PAR3, and PAR6 are expressed in ENS precursors with protein localization to the axon tip in a pattern resembling that seen in developing hippocampal or dorsal root ganglion cells. Furthermore, globally inhibiting either GSK3 $\beta$ or PKC $\zeta$ in ENS precursors increases the production of multi-axonal neurons, reduces axon growth, and slows the migration of ENS precursors through the distal bowel. These effects are consistent with a role for GSK3 $\beta$ and $\mathrm{PKC} \zeta$ in ENS precursor polarization.

Recently, SMURF1 has been demonstrated to regulate cell polarity in model cell lines by targeting RhoA for degradation (Wang et al., 2003, 2006; Zhang et al., 2004; Ozdamar et al., 2005; Boyer et al., 2006) and to promote neurite growth in Neuro2A cells by the same mechanism (Bryan et al., 2005). SMURF1 also has other substrates including SMAD proteins activated by bone morphogenetic protein (BMP) signaling (Zhu et al., 1999; Barrios-Rodiles et al., 2005; Alexandrova and Thomsen, 2006), TGF $\beta$ and BMP type I receptors (Kavsak et al., 2000; Ebisawa et al., 2001), and Runx2 (runt related transcription factor 2) (Zhao et al., 2003). In the present study, we demonstrate that SMURF1 is expressed in developing mammalian neurons and localized in the cell body and axon tip in a similar distribution to other proteins controlling cell polarity. We also demonstrate that SMURF1 interacts with the polarity complex proteins including PAR6. These data suggested the possibility that SMURF1 and RhoA signaling might be important for ENS precursor polarization. To test this hypothesis, immunoselected ENS precursors were 
infected with a virus expressing Smurf1 siRNA or control siRNA. Although Smurf1 siRNA-expressing cells had markedly reduced neurite length, there was no increase in axon number in cells with reduced SMURF1 production. This was true even in the presence of ROCK inhibitor that permitted neurite growth from most cells. We further demonstrated that silencing SMURF1 does not influence the polarized distribution of PAR3. Finally, the observation that ROCK inhibitor did not affect neuronal polarity or neurite length in control siRNA-treated cells suggests that, under normal growth conditions, RhoA activity is already low in developing axons because of SMURF1. Thus, although SMURF1 and RhoA/ROCK signaling are important for neurite growth in ENS precursors, there is no clear role for these proteins in ENS precursor polarity.

These findings have important implications for a common potentially fatal human disease in which failure of neural crestderived precursor migration results in distal colonic aganglionosis. This disorder, called Hirschsprung disease (Skinner, 1996), which affects 1:5000 human infants, has complex genetics with incomplete penetrance and variable expressivity. This occurs because most affected individuals have a combination of hypomorphic mutations that cause aganglionosis (Gabriel et al., 2002; McCallion et al., 2003; Vohra et al., 2006). In particular, reduced signaling by the Ret transmembrane tyrosine kinase is a major risk factor for Hirschsprung disease. For this reason, defining molecular mechanisms through which Ret signaling encourages ENS precursor migration and differentiation is critical for understanding Hirschsprung disease risk factors and may suggest novel methods for preventing or treating this disorder. Furthermore, although enteric neurons have long been appreciated to have complex and diverse patterns of axon growth, almost nothing was previously known about mechanisms that might control neurite specification within the ENS.

Ret is expressed in ENS precursors in which it is the signaling receptor for the GDNF family of ligands (glial cell line-derived neurotrophic factor, neurturin, artemin, and persephin) (Baloh et al., 2000; Manie et al., 2001; Takahashi, 2001; Airaksinen and Saarma, 2002). Substantial work over the past 10 years has demonstrated that GDNF/Ret signaling is important for ENS precursor survival, proliferation, migration, and differentiation (Pichel et al., 1996; Sanchez et al., 1996; Chalazonitis et al., 1998; Enomoto et al., 1998; Hearn et al., 1998; Heuckeroth et al., 1998; Taraviras et al., 1999; Young et al., 2001; Gianino et al., 2003). In fact, gradients of GDNF expression within the bowel are thought to be important for promoting directed ENS precursor migration. For these reasons, Ret signaling pathways have been investigated in many model systems, but mechanisms linking Ret activation to changes in the cytoskeleton needed for directed cell migration or neurite growth are incompletely understood.

New data presented, when combined with known Ret signaling pathways, directly link Ret activation at the cell surface to intracellular molecular machinery that regulates the cytoskeleton and suggest a model through which Ret signaling might control neurite outgrowth, cell polarization, and migration of ENS precursors (Fig. 10).
This signal begins with localized phosphatidylinositol 3-kinase (PI3) kinase activation, which is also essential for ENS precursor survival, neurite outgrowth, and directed migration (Natarajan et al., 2002; Srinivasan et al., 2005). Because PI3 kinase signaling is required for cell survival, however, PI3 kinase effects on neurite growth or precursor migration are difficult to interpret. Furthermore, previous studies of ENS development ignored the issue of polarization that is required for axon specification and directed migration. These mechanisms have, however, been investigated previously in a number of other cell types (Hirai and Chida, 2003; Arimura and Kaibuchi, 2005; Charest and Firtel, 2006; Yoshimura et al., 2006) in which migration, neurite growth, and specification are controlled by different cell surface receptors. In ENS precursors, localized PI3 kinase activation occurs after Ret phosphorylation at tyrosine 1062 (Hayashi et al., 2000; Takahashi, 2001; Kurokawa et al., 2003). PI3 kinase then phosphorylates phosphatidyl inositol $[\mathrm{PI}(4,5) \mathrm{P} 2]$ to generate $\mathrm{PI}(3,4,5) \mathrm{P} 3\left[\mathrm{PIP}_{3}\right]$, which in turn leads to local recruitment to the cell membrane and activation of pleckstrin homology domain proteins, including protein kinase B (also known as AKT), 3'-PIdependent protein kinase 1 (PDK1), and integrin-linked kinase (Yoganathan et al., 2000). PDK1 phosphorylates and activates PKC $\zeta$, whereas $\mathrm{PIP}_{3}$ also stimulates $\mathrm{PKC} \zeta$ autophosphorylation (Hirai and Chida, 2003). In addition, PI3 kinase or $\mathrm{PIP}_{3}$ and PDK1 greatly enhance the activity of GDP/GTP exchange factors (GEF) that activate Rho family GTPases such as Racl and Cdc42 (Tian et al., 2002; Innocenti et al., 2003). PI3 kinase activation is also required for the localization of PAR complex proteins, $\mathrm{PKC} \zeta$, and $\mathrm{Cdc} 42$ to the tips of growing axons (Yoshimura et al., 2006). Cdc42 is then thought to activate Rac1 via PAR3 and the Tiam1 (T-cell lymphoma invasion and metastasis 1) GEF (Matsuo et al., 2003; Nishimura et al., 2005). Because Rac1 directly activates PI3 kinase, localized activation of PI3 kinase by receptor tyrosine kinases such as Ret can lead to the formation of a positive feedback loop that facilitates rapid axon extension or directed cell migration. Once this activated complex is en- 
riched at the leading edge of the migrating cell or the tip of the growing axon, changes in actin filament and microtubule dynamics can be mediated by Rho family GTPases and PKC $\zeta$.

In parallel with $\mathrm{PI} 3$ kinase/PKC $\zeta$-mediated signaling, localized inhibition of GSK3 $\beta$ is also essential for polarized outgrowth of single axons from hippocampal (Shi et al., 2004; Jiang et al., 2005; Yoshimura et al., 2005; Gartner et al., 2006) and dorsal root ganglion (Zhou et al., 2004) neurons and for migration of astrocytes (EtienneManneville and Hall, 2003b). This localized GSK3 $\beta$ inhibition appears to be required for adenomatous polyposis coli- and kinesinmediated transport of PAR3 to the plus ends of rapidly growing microtubules (Shi et al., 2004; Zhou et al., 2004). In contrast to these other neuron types, however, some enteric neurons normally produce multiple axons, suggesting the possibility that reducing $\mathrm{PKC} \zeta$ or GSK3 $\beta$ signaling could be part of the mechanism for producing multi-axonal enteric neuron subtypes in vivo. Interestingly, inhibition of GSK3 $\beta$ could be mediated by AKT, integrin linked kinase (Arevalo and Chao, 2005), or directly by PKC $\zeta$ (Etienne-Manneville and Hall, 2003b). Thus, the observation that blocking either PKC $\zeta$ or GSK3 $\beta$ has a similar effect on axon growth and polarization in the ENS is consistent with the hypothesis that local activity of these kinases is essential for normal development. For this reason, global inhibition of kinase activity both increases axon number and slows precursor migration by disrupting normal cell polarity.

Together, these observations provide novel insight into molecular mechanisms critical for formation of the ENS. Specifically, we demonstrate for the first time that proteins controlling neuronal polarity and axon number (PKC $\zeta$ and GSK $3 \beta$ ) are also essential for ENS precursor migration through the bowel. In addition, we find that, although SMURF1 is essential for neurite growth, associates with other proteins controlling polarity, and influences polarity in other cell types, altering SMURF1 or ROCK signaling does not influence axon number in the developing enteric neurons. Finally, although PCK $\zeta$ and GSK $3 \beta$ activity are not required for survival of ENS precursors, we predict that polymorphisms in GSK3 $\beta$ or PKC $\zeta$ could alter Hirschsprung disease penetrance or expressivity and contribute to the variable phenotypes observed even within family members that share the same Ret mutation by reducing the migration of ENS precursors through the distal bowel.

Note added in proof. A recent manuscript demonstrates that Smurf1 is important for neurite growth but not neuronal polarity in hippocampal neurons (Schwamborn et al., 2007). The same authors demonstrate that the related protein Smurf2 regulates neuronal polarity by ubiquitinating and targeting Rap $1 \mathrm{~B}$ for degradation. These observations agree with our findings about the role of Smurf1 in enteric neurons.

\section{References}

Airaksinen MS, Saarma M (2002) The GDNF family: signalling, biological functions and therapeutic value. Nat Rev Neurosci 3:383-394.

Alexandrova EM, Thomsen GH (2006) Smurf1 regulates neural patterning and folding in Xenopus embryos by antagonizing the BMP/Smad1 pathway. Dev Biol 299:398-410.

Arevalo JC, Chao MV (2005) Axonal growth: where neurotrophins meet Wnts. Curr Opin Cell Biol 17:112-115.

Arimura N, Kaibuchi K (2005) Key regulators in neuronal polarity. Neuron 48:881-884.

Baloh RH, Enomoto H, Johnson EMJ, Milbrandt J (2000) The GDNF family ligands and receptors-implications for neural development. Curr Opin Neurobiol 10:103-110.

Barlow A, de Graaff E, Pachnis V (2003) Enteric nervous system progenitors are coordinately controlled by the $G$ protein-coupled receptor EDNRB and the receptor tyrosine kinase RET. Neuron 40:905-916.

Barrios-Rodiles M, Brown KR, Ozdamar B, Bose R, Liu Z, Donovan RS, Shinjo F, Liu Y, Dembowy J, Taylor IW, Luga V, Przulj N, Robinson M,
Suzuki H, Hayashizaki Y, Jurisica I, Wrana JL (2005) High-throughput mapping of a dynamic signaling network in mammalian cells. Science 307:1621-1625.

Bito H, Furuyashiki T, Ishihara H, Shibasaki Y, Ohashi K, Mizuno K, Maekawa M, Ishizaki T, Narumiya S (2000) A critical role for a Rhoassociated kinase, p160ROCK, in determining axon outgrowth in mammalian CNS neurons. Neuron 26:431-441.

Boyer L, Turchi L, Desnues B, Doye A, Ponzio G, Mege JL, Yamashita M, Zhang YE, Bertoglio J, Flatau G, Boquet P, Lemichez E (2006) CNF1induced ubiquitylation and proteasome destruction of activated RhoA is impaired in Smurf1-/- cells. Mol Biol Cell 17:2489-2497.

Brehmer A, Schrodl F, Neuhuber W (1999) Morphological classifications of enteric neurons-100 years after Dogiel. Anat Embryol (Berl) 200:125-135.

Bryan B, Cai Y, Wrighton K, Wu G, Feng XH, Liu M (2005) Ubiquitination of RhoA by Smurf1 promotes neurite outgrowth. FEBS Lett 579:1015-1019.

Chalazonitis A, Rothman TP, Chen J, Gershon MD (1998) Age-dependent differences in the effects of GDNF and NT-3 on the development of neurons and glia from neural crest-derived precursors immunoselected from the fetal rat gut: expression of GFR $\alpha-1$ in vitro and in vivo. Dev Biol 204:385-406.

Chant J (1999) Cell polarity in yeast. Annu Rev Cell Dev Biol 15:365-391.

Charest PG, Firtel RA (2006) Feedback signaling controls leading-edge formation during chemotaxis. Curr Opin Genet Dev 16:339-347.

Cole AR, Knebel A, Morrice NA, Robertson LA, Irving AJ, Connolly CN, Sutherland C (2004) GSK-3 phosphorylation of the Alzheimer epitope within collapsin response mediator proteins regulates axon elongation in primary neurons. J Biol Chem 279:50176-50180.

Dogiel AS (1899) Ueber den bau der ganglien in den geflechten des darmes und der gallenblase des menschen und der saugethiere. Arch Anat Physiol Leip Anat Abt Jg 1899:130-158.

Ebisawa T, Fukuchi M, Murakami G, Chiba T, Tanaka K, Imamura T, Miyazono K (2001) Smurf1 interacts with transforming growth factor-beta type I receptor through Smad7 and induces receptor degradation. J Biol Chem 276:12477-12480.

Enomoto H, Araki T, Jackman A, Heuckeroth RO, Snider WD, Johnson EMJ, Milbrandt J (1998) GFR $\alpha 1$ deficient mice have deficits in the enteric nervous system and kidneys. Neuron 21:317-324.

Etienne-Manneville S, Hall A (2001) Integrin-mediated activation of Cdc42 controls cell polarity in migrating astrocytes through PKCzeta. Cell 106:489-498.

Etienne-Manneville S, Hall A (2003a) Cell polarity: Par6, aPKC and cytoskeletal crosstalk. Curr Opin Cell Biol 15:67-72.

Etienne-Manneville S, Hall A (2003b) Cdc42 regulates GSK-3beta and adenomatous polyposis coli to control cell polarity. Nature 421:753-756.

Furness JB (2000) Types of neurons in the enteric nervous system. J Auton Nerv Syst 81:87-96.

Gabriel SB, Salomon R, Pelet A, Angrist M, Amiel J, Fornage M, Attie-Bitach T, Olson JM, Hofstra R, Buys C, Steffann J, Munnich A, Lyonnet S, Chakravarti A (2002) Segregation at three loci explains familial and population risk in Hirschsprung disease. Nat Genet 31:89-93.

Gartner A, Huang X, Hall A (2006) Neuronal polarity is regulated by glycogen synthase kinase-3 (GSK-3 $\beta$ ) independently of Akt/PKB serine phosphorylation. J Cell Sci 119:3927-3934.

Gershon M (1997) Genes and lineages in the formation of the enteric nervous system. Curr Opin Neurobiol 7:101-109.

Gianino S, Grider JR, Cresswell J, Enomoto H, Heuckeroth RO (2003) GDNF availability determines enteric neuron number by controlling precursor proliferation. Development 130:2187-2198.

Hayashi H, Ichihara M, Iwashita T, Murakami H, Shimono Y, Kawai K, Kurokawa K, Murakumo Y, Imai T, Funahashi H, Nakao A, Takahashi M (2000) Characterization of intracellular signals via tyrosine 1062 in RET activated by glial cell line-derived neurotrophic factor. Oncogene 19:4469-4475.

Hearn CJ, Murphy M, Newgreen D (1998) GDNF and ET-3 differentially modulate the numbers of avian enteric neural crest cells and enteric neurons in vitro. Dev Biol 197:93-105.

Heuckeroth RO, Lampe PA, Johnson EMJ, Milbrandt J (1998) Neurturin and GDNF promote proliferation and survival of enteric neuron and glial progenitors in vitro. Dev Biol 200:116-129.

Higginbotham H, Tanaka T, Brinkman BC, Gleeson JG (2006) GSK3beta 
and PKCzeta function in centrosome localization and process stabilization during Slit-mediated neuronal repolarization. Mol Cell Neurosci 32:118-132.

Hirai T, Chida K (2003) Protein kinase Czeta (PKCzeta): activation mechanisms and cellular functions. J Biochem (Tokyo) 133:1-7.

Huber LJ, Chao MV (1995) Mesenchymal and neuronal cell expression of the p75 neurotrophin receptor gene occur by different mechanisms. Dev Biol 167:227-238.

Innocenti M, Frittoli E, Ponzanelli I, Falck JR, Brachmann SM, Di Fiore PP, Scita G (2003) Phosphoinositide 3-kinase activates Rac by entering in a complex with Eps8, Abi1, and Sos-1. J Cell Biol 160:17-23.

Jiang H, Guo W, Liang X, Rao Y (2005) Both the establishment and the maintenance of neuronal polarity require active mechanisms: critical roles of GSK-3beta and its upstream regulators. Cell 120:123-135.

Jope RS, Johnson GV (2004) The glamour and gloom of glycogen synthase kinase-3. Trends Biochem Sci 29:95-102.

Kavsak P, Rasmussen RK, Causing CG, Bonni S, Zhu H, Thomsen GH, Wrana JL (2000) Smad7 binds to Smurf2 to form an E3 ubiquitin ligase that targets the TGF beta receptor for degradation. Mol Cell 6:1365-1375.

Kemphues KJ, Priess JR, Morton DG, Cheng NS (1988) Identification of genes required for cytoplasmic localization in early C. elegans embryos. Cell 52:311-320.

Kim WY, Zhou FQ, Zhou J, Yokota Y, Wang YM, Yoshimura T, Kaibuchi K, Woodgett JR, Anton ES, Snider WD (2006) Essential roles for GSK-3s and GSK-3-primed substrates in neurotrophin-induced and hippocampal axon growth. Neuron 52:981-996.

Kurokawa K, Kawai K, Hashimoto M, Ito Y, Takahashi M (2003) Cell signalling and gene expression mediated by RET tyrosine kinase. J Intern Med 253:627-633.

Lin D, Edwards AS, Fawcett JP, Mbamalu G, Scott JD, Pawson T (2000) A mammalian PAR-3-PAR-6 complex implicated in Cdc42/Rac1 and aPKC signalling and cell polarity. Nat Cell Biol 2:540-547.

Manie S, Santoro M, Fusco A, Billaud M (2001) The RET receptor: function in development and dysfunction in congenital malformation. Trends Genet 17:580-589.

Matsuo N, Terao M, Nabeshima Y, Hoshino M (2003) Roles of STEF/ Tiam1, guanine nucleotide exchange factors for Rac1, in regulation of growth cone morphology. Mol Cell Neurosci 24:69-81.

McCallion AS, Stames E, Conlon RA, Chakravarti A (2003) Phenotype variation in two-locus mouse models of Hirschsprung disease: tissue-specific interaction between Ret and Ednrb. Proc Natl Acad Sci USA 100:1826-1831.

Nance J (2005) PAR proteins and the establishment of cell polarity during $C$. elegans development. BioEssays 27:126-135.

Natarajan D, Marcos-Gutierrez C, Pachnis V, De Graaff E (2002) Requirement of signalling by receptor tyrosine kinase RET for the directed migration of enteric nervous system progenitor cells during mammalian embryogenesis. Development 129:5151-5160.

Newgreen D, Young HM (2002a) Enteric nervous system: development and developmental disturbances-part 1. Pediatr Dev Pathol 5:224-247.

Newgreen D, Young HM (2002b) Enteric nervous system: development and developmental disturbances—part 2. Pediatr Dev Pathol 5:329-349.

Nishimura T, Yamaguchi T, Kato K, Yoshizawa M, Nabeshima Y, Ohno S, Hoshino M, Kaibuchi K (2005) PAR-6-PAR-3 mediates Cdc42-induced Rac activation through the Rac GEFs STEF/Tiam1. Nat Cell Biol 7:270-277.

Ozdamar B, Bose R, Barrios-Rodiles M, Wang HR, Zhang Y, Wrana JL (2005) Regulation of the polarity protein Par6 by TGFbeta receptors controls epithelial cell plasticity. Science 307:1603-1609.

Pichel JG, Shen L, Hui SZ, Granholm A-C, Drago J, Grinberg A, Lee EJ, Huang SP, Saarma M, Hoffer BJ, Sariola H, Westphal H (1996) Defects in enteric innervation and kidney development in mice lacking GDNF. Nature 382:73-76.

Qin XF, An DS, Chen IS, Baltimore D (2003) Inhibiting HIV-1 infection in human $\mathrm{T}$ cells by lentiviral-mediated delivery of small interfering RNA against CCR5. Proc Natl Acad Sci USA 100:183-188.

Quach TT, Duchemin AM, Rogemond V, Aguera M, Honnorat J, Belin MF, Kolattukudy PE (2004) Involvement of collapsin response mediator proteins in the neurite extension induced by neurotrophins in dorsal root ganglion neurons. Mol Cell Neurosci 25:433-443.
Sanchez MP, Silos-Santiago I, Frisen J, He B, Lira SA, Barbacid M (1996) Renal agenesis and the absence of enteric neurons in mice lacking GDNF. Nature 382:70-73.

Schwamborn JC, Muller M, Becker AH, Puschel AW (2007) Ubiquitination of the GTPase Rap1B by the ubiquitin ligase Smurf2 is required for the establishment of neuronal polarity. EMBO J 26:1410-1422.

Shi SH, Jan LY, Jan YN (2003) Hippocampal neuronal polarity specified by spatially localized mPar3/mPar6 and PI 3-kinase activity. Cell 112:63-75.

Shi SH, Cheng T, Jan LY, Jan YN (2004) APC and GSK-3beta are involved in mPar3 targeting to the nascent axon and establishment of neuronal polarity. Curr Biol 14:2025-2032.

Skinner M (1996) Hirschsprung's disease. Curr Probl Surg 33:391-461.

Srinivasan S, Anitha M, Mwangi S, Heuckeroth RO (2005) Enteric neuroblasts require the phosphatidylinositol 3-kinase/Akt/Forkhead pathway for GDNF-stimulated survival. Mol Cell Neurosci 29:107-119.

Takahashi M (2001) The GDNF/RET signaling pathway and human diseases. Cytokine Growth Factor Rev 12:361-373.

Taraviras S, Marcos-Gutierrez CV, Durbec P, Jani H, Grigoriou M, Sukumaran M, Wang L-C, Hynes M, Raisman G, Pachnis V (1999) Signalling by RET receptor tyrosine kinase and its role in the development of the mammalian enteric nervous system. Development 126:2785-2797.

Tian X, Rusanescu G, Hou W, Schaffhausen B, Feig LA (2002) PDK1 mediates growth factor-induced Ral-GEF activation by a kinase-independent mechanism. EMBO J 21:1327-1338.

Vohra BPS, Planer W, Armon J, Fu M, Jain S, Heuckeroth R (2006) Reduced entothelin converting enzyme- 1 and endothelin-3 mRNA in the developing bowel of male mice may increase expressivity and penetrance of Hirschsprung disease like distal intestinal aganglionosis. Dev Dyn 236:106-117.

Wang HR, Zhang Y, Ozdamar B, Ogunjimi AA, Alexandrova E, Thomsen GH, Wrana JL (2003) Regulation of cell polarity and protrusion formation by targeting RhoA for degradation. Science 302:1775-1779.

Wang HR, Ogunjimi AA, Zhang Y, Ozdamar B, Bose R, Wrana JL (2006) Degradation of RhoA by Smurf1 ubiquitin ligase. Methods Enzymol 406:437-447.

Wiggin GR, Fawcett JP, Pawson T (2005) Polarity proteins in axon specification and synaptogenesis. Dev Cell 8:803-816.

Wodarz A (2002) Establishing cell polarity in development. Nat Cell Biol 4:E39-E44.

Wu JJ, Chen J-X, Rothman TP, Gershon MD (1999) Inhibition of in vitro enteric neuronal development by endothelin-3: mediation by endothelin B receptors. Development 126:1161-1173.

Yoganathan TN, Costello P, Chen X, Jabali M, Yan J, Leung D, Zhang Z, Yee A, Dedhar S, Sanghera J (2000) Integrin-linked kinase (ILK): a "hot" therapeutic target. Biochem Pharmacol 60:1115-1119.

Yoshimura T, Kawano Y, Arimura N, Kawabata S, Kikuchi A, Kaibuchi K (2005) GSK-3beta regulates phosphorylation of CRMP-2 and neuronal polarity. Cell 120:137-149.

Yoshimura T, Arimura N, Kaibuchi K (2006) Signaling networks in neuronal polarization. J Neurosci 26:10626-10630.

Young HM, Hearn CJ, Farlie PG, Canty AJ, Thomas PQ, Newgreen DF (2001) GDNF is a chemoattractant for enteric neural cells. Dev Biol 229:503-516.

Yu JY, Taylor J, DeRuiter SL, Vojtek AB, Turner DL (2003) Simultaneous inhibition of GSK3alpha and GSK3beta using hairpin siRNA expression vectors. Mol Ther 7:228-236.

Zhang Y, Wang HR, Wrana JL (2004) Smurf1: a link between cell polarity and ubiquitination. Cell Cycle 3:391-392.

Zhao M, Qiao M, Oyajobi BO, Mundy GR, Chen D (2003) E3 ubiquitin ligase Smurf1 mediates core-binding factor alpha1/Runx2 degradation and plays a specific role in osteoblast differentiation. J Biol Chem 278:27939-27944.

Zhou FQ, Zhou J, Dedhar S, Wu YH, Snider WD (2004) NGF-induced axon growth is mediated by localized inactivation of GSK-3beta and functions of the microtubule plus end binding protein APC. Neuron 42:897-912.

Zhu H, Kavsak P, Abdollah S, Wrana JL, Thomsen GH (1999) A SMAD ubiquitin ligase targets the BMP pathway and affects embryonic pattern formation. Nature 400:687-693. 